\title{
Total Phenolic Content, Free Radical Scavenging Activity and Reducing Power of Quisqualis indica Linn.
}

\author{
Md. Abul Kaisar ${ }^{1}$, Mohammad Rashedul Islam², Mohammad Sarifur Rahman ${ }^{1}$, \\ Md. Khalid Hossain ${ }^{1}$ and Mohammad A. Rashid ${ }^{1,3}$ \\ ${ }^{1}$ Department of Pharmaceutical Chemistry, Faculty of Pharmacy, University of Dhaka, \\ Dhaka-1000, Bangladesh \\ ${ }^{2}$ Department of Pharmacy, State University of Bangladesh, Dhaka-1205, Bangladesh \\ ${ }^{3}$ Centre for Biomedical Research, University of Dhaka, Dhaka-1000, Bangladesh
}

Quisqualis indica Linn. (Family- Combretaceae), locally known as Madhabilata or modhumaloti, is a perennial ornamental plant having 15-20 feet height. It is distributed all over the Bangladesh. Traditionaly this plant is used as antifungal agent, ${ }^{1}$ to treat ascariasis, oxyuriasis, ${ }^{2}$ diarrhea, fever, rickets, abdominal pain and rheumatism. ${ }^{3}$ No studies have been conducted to investigate the antioxidant potential of $Q$. indica. In the present study, the different partitionates of methanolic extract of stem bark were used to investigate the antioxidant activity in terms of total phenolic content, free radical scavenging activity and reducing power determination. We herein reported a correlation between the antioxidant activity, reducing power and total phenolic content.

The stem bark of Quisqualis indica was collected from Dhaka, Bangladesh, in August 2005. A voucher specimen (DACB-312338) of this collection has been deposited in the Bangladesh National Herbarium, Mirpur, Dhaka. The sundried and powdered stem bark $(1.0 \mathrm{Kg})$ of $Q$. indica was macerated in $2.5 \mathrm{~L}$ of methanol for 7 days and then

Correspondence to: Mohammad A. Rashid

Tel.:880-2-8612069, 9661900-73, extn. 4363, 4364, 8137

Fax: 880-2-8612069

E-mail: rashidma@univdhaka.edu; rashid_phdu@yahoo.com

Dhaka Univ. J. Pharm. Sci. 8(2): 173-175, 2009 (December) filtered through a cotton plug followed by Whatman filter paper number 1 . The extract was concentrated with a rotary evaporator at low temperature (40$45^{\circ} \mathrm{C}$ ) and reduced pressure. An aliquot of the concentrated methanolic extract was then partitioned by modified Kupchan method ${ }^{4}$ and the resultant partitionates i.e., n-hexane (HSP), carbon tetrachloride (CTP), chloroform (CSP) and aqueous (ASP) soluble fractions are used for the experimental process.

Total phenolic content of $Q$. indica extractives was measured by employing the method described by Skerget et al. ${ }^{5}$ involving Folin-Ciocalteu reagent as an oxidizing agent and gallic acid as a standard. To $0.5 \mathrm{ml}$ of extract solution ( $2 \mathrm{mg} / \mathrm{ml}$ ) in water, $2.5 \mathrm{ml}$ of Folin-Ciocalteu reagent (diluted 10 times with water) and $2.0 \mathrm{ml}$ of sodium carbonate $(7.5 \% \mathrm{w} / \mathrm{v})$ solution were added. The mixture was then incubated for 20 minutes at room temperature. After 20 minutes the absorbance was measured at $760 \mathrm{~nm}$ using a UVvisible spectrophotometer. Total phenolics were quantified by calibration curve obtained from measuring the known concentrations of gallic acid (0$100 \mu \mathrm{g} / \mathrm{ml}$ ). The phenolic contents of the sample were expressed as gm of GAE (gallic acid equivalent) / $100 \mathrm{gm}$ of the dried extract.

The free radical scavenging activity (antioxidant capacity) of the plant extractives on the stable radical 
1,1-diphenyl-2-picrylhydrazyl (DPPH) were estimated by the method established by BrandWilliams et al. ${ }^{6}$ Two $\mathrm{ml}$ of a methanol solution of the sample (extractive/standard) at different concentrations ( $500 \mu \mathrm{g} / \mathrm{ml}$ to $0.977 \mu \mathrm{g} / \mathrm{ml}$ ) were mixed with $3.0 \mathrm{ml}$ of a DPPH methanol solution $(20 \mu \mathrm{g} / \mathrm{ml})$. After 30 mins of reaction at room temperature in dark place the absorbance was measured at $517 \mathrm{~nm}$ against methanol as blank by using UV spetrophotometer.

Inhibition of free radical DPPH in percent (I\%) was calculated as follows:

$$
(\mathrm{I} \%)=\left(1-\mathrm{A}_{\text {sample }} / \mathrm{A}_{\text {blank }}\right) \mathrm{X} 100
$$

Where $A_{\text {blank }}$ is the absorbance of the control (containing all reagents except the test material).

Extract concentration providing 50\% inhibition $\left(\mathrm{IC}_{50}\right)$ was calculated from the graph plotted inhibition percentage against extractive/standard concentration.

A spectrophotometric method ${ }^{7}$ was used for the measurement of reducing power. For this $2.5 \mathrm{ml}$ of each extract was mixed with $2.5 \mathrm{ml}$ phosphate buffer (0.2 M, pH 6.6) and $2.5 \mathrm{ml}$ of $1 \%$ potassium ferricyanide $(10 \mathrm{mg} / \mathrm{ml})$. The mixture was incubated at $50^{\circ} \mathrm{C}$ for $20 \mathrm{~min}$, then rapidly cooled, mixed with $2.5 \mathrm{ml}$ of $10 \%$ trichloroacetic acid and centrifuged at $6500 \mathrm{rpm}$ for $10 \mathrm{~min}$. The supernatant $(2.5 \mathrm{ml})$ was diluted with distilled water $(2.5 \mathrm{ml})$ and then ferric chloride $(0.5 \mathrm{ml}, 0.1 \%)$ was added and allowed to stand for $10 \mathrm{~min}$. The absorbance was read spectrophotometrically at $700 \mathrm{~nm}$. BHT (200, 100, 50, 25, 12.5 and $6.25 \mathrm{mg} / \mathrm{ml}$ ) were used as standard for construction of the calibration curve and the reducing power activities were reported as BHT equivalent per 100 gm dry sample.

Three replicates of each sample were used for statistical analysis and the values were reported as mean \pm SD. Correlation analysis of free radical scavenging activity versus total phenolic content and reducing power were carried out using the correlation and regression program.

The present study was undertaken to evaluate the antoxidant activity of different partitionates of the methanolic extract of the stem bark of $Q$. indica. The results are given in Table 1 . The amount of total phenolic content varied for different partitionates ranging from $22.95 \mathrm{gm}$ to $39.45 \mathrm{gm}$ of GAE/100 gm of dried extract. The highest total phenolics was found in CSP (39.45 gm of GAE/100 gm of dried extract) and the lowest in HSP (22.95 gm of GAE/100 gm of dried extract). Total phenolics content of carbon tetrachloride and aqueous soluble part were found to be 30.81 and $29.87 \mathrm{gm}$ of GAE/100 gm of dried extract, respectively. Among the partitionates tested, the most potent fraction was found to be chloroform soluble part. Free radical scavenging activity of the CSP was highest having IC $_{50}$ value of $30.65 \mu \mathrm{g} / \mathrm{ml}$. CTP, ASP and HSP demonstrated moderate free radical scavenging activity with the $\mathrm{IC}_{50}$ value of $68.46,72.20$ and 84.23 $\mu \mathrm{g} / \mathrm{ml}$, respectively, as compared to the standards, i.e. tert-butyl-1-hydroxytoluene (BHT), $\left(\mathrm{IC}_{50}=24.35\right.$ $\mu \mathrm{g} / \mathrm{ml}$ ) and ascorbic acid, ASA ( $\left.\mathrm{IC}_{50}=5.80 \mu \mathrm{g} / \mathrm{ml}\right)$.

Table 1. Total phenolic content, free radical scavenging activity and reducing power of different partitionates of $Q$. indica.

\begin{tabular}{lccc}
\hline Sample & $\begin{array}{c}\text { Total Phenolic } \\
\text { Content (gm of } \\
\text { GAE/100 gm of } \\
\text { dried extract) }\end{array}$ & $\begin{array}{c}\text { Free Radical } \\
\text { Scavenging } \\
\text { Activity } \\
\text { (IC } 50 \mu \mathrm{g} / \mathrm{ml})\end{array}$ & $\begin{array}{c}\text { Reducing Power } \\
\text { (gm of BHT/ } \\
100 \text { gm of dried } \\
\text { extract) }\end{array}$ \\
\hline BHT & - & $24.35 \pm 0.21$ & - \\
ASA & - & $5.80 \pm 0.21$ & - \\
HSP & $22.95 \pm 0.357$ & $84.23 \pm 0.312$ & $11.36 \pm 0.129$ \\
CTP & $30.81 \pm 0.066$ & $68.46 \pm 0.225$ & $36.09 \pm 0.283$ \\
CSP & $39.45 \pm 0.093$ & $30.65 \pm 0.321$ & $63.18 \pm 0.246$ \\
ASP & $29.87 \pm 0.039$ & $72.20 \pm 0.176$ & $22.81 \pm 0.372$ \\
\hline
\end{tabular}

*The average values of three calculations are presented as mean \pm S.D. (standard deviation)

Like antioxidant activity, the highest reducing power was detected for CSP (63.18 gm of BHT/100 gm of dried extract) followed by $36.09 \mathrm{gm}$ of BHT/100 gm of dried extract for CTP. Lowest reducing power was observed in case of HSP with $11.36 \mathrm{gm}$ of BHT/ $100 \mathrm{gm}$ of dried extract. Among the partitionates tested, the most potent fraction was found to be chloroform soluble fraction having the highest total phenolics and reducing power, free radical scavenging activity; this indicated that this fraction possessed maximum antioxidant capabilities.

The correlation analysis revealed that a correlation exists between the free radical scavenging 
activity, total phenolic content and reducing power. The correlation coefficient (R) for the total phenolic content and free radical scavenging activity (Figure 1) was 0.9368 indicating a relationship between the total phenolics and the free radical scavenging activity and the $\mathrm{R}$ is 0.955 for free radical scavenging activity and reducing power (Figure 2). This result suggests

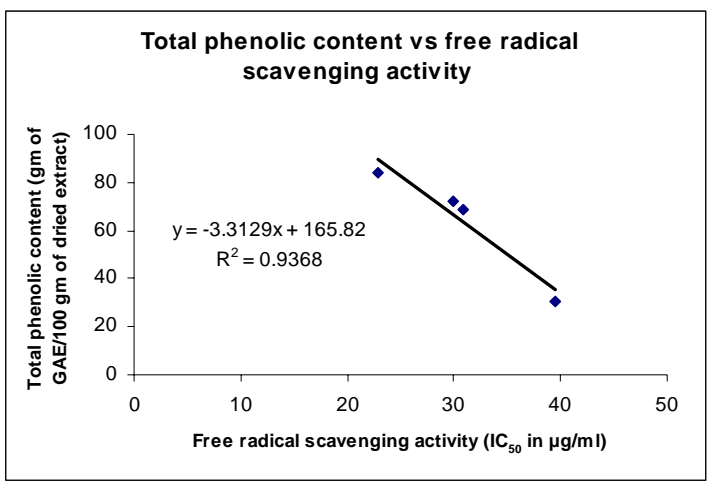

Figure 1. Total phenolic content vs free radical scavenging activity

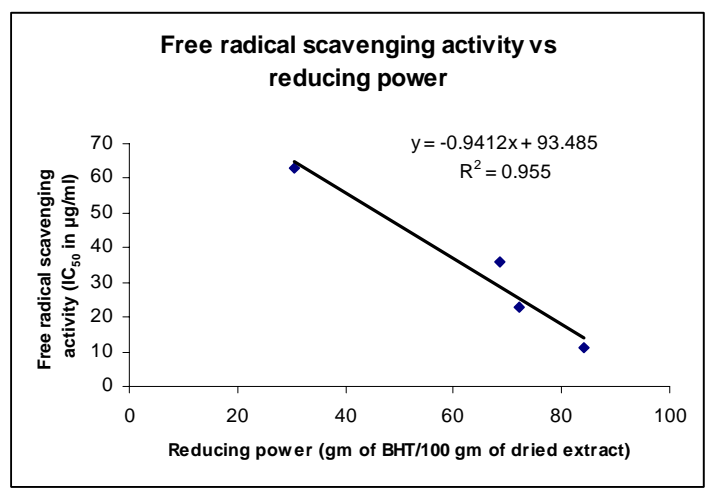

Figure 2. Free radical scavenging activity vs reducing power

that $93 \%$ of the free radical scavenging activity resulted from the contribution of the phenolic compounds. Different secondary metabolites, such as volatile oils, carotenoids and vitamins may also contribute to the antioxidant capacity, which in this case contributed to approximately $7 \%$ of the free radical scavenging activity. On the other hand, about 95\% antioxidant activity was due to the redox properties, which allowed them to act as reducing agents. ${ }^{8,9}$ The present study showed that the partitionates of the methanolic extract of $Q$. indica (stem bark) especially the choloroform soluble fraction possesses significant antioxidant potentials whereas the other partitionates exhibited moderate activity suggesting the rationale for further investigations.

\section{REFFERENCES}

1. Bangs, M. J., Purnomo, E.M., Andersen, E.M. and Anthony, R.L. 1996. Screening of Indonesian plants for antifungal and free radical scavenging activities. Pharmaceutical. Biol. 37, 260-268.

2. Beers, M.H. and Berkow, R., 1999. The Merck Manual of Diagnosis and Therapy. Whitehouse Station, NJ: Merck Research Laboratories. Section 13, Chapter 161.

3. Padua De, L. S., Bunyapraphatsara, N. and Lemmens R.H.M.J., 1999. PROSEA. Plant Resources of South-East Asia No. 12: Medicinal and Poisonous Plants 1.

4. Van Wagenen, B.C., Larsen, R., Cardellina, J.H. II, Ran dazzo, D., Lidert, Z.C. and Swithenbank, C. 1993. Ulosantoin, a potent insecticide from the sponge Ulosa ruetzleri. J. Org. Chem. 58, 335-337.

5. Skerget, M., Kotnik, P., Hadolin, M., Hras, A., Simonic, M. and Knez, Z., 2005. Phenols, proanthocyanidins, flavones and flavonols in some plant materials and their antioxidant activities. Food. chem. 89, 191-198.

6. Brand-Williams, W., Cuvelier, M. E.and Berset, C., 1995. Use of free radical method to evaluate antioxidant activity. Lebensm. Wiss. Technol. 28, 25-30.

7. Ferreira, I.C.F.R., Baptista, M., Vilas-Boas and Barros, L., 2007. Free radical scavenging capacity and reducing power of wild edible mushrooms from northeast Portugal: Individual cap and stipe activity. Food Chem. 100, 15111516.

8. Odabasoglu, F., Aslan, A., Cakir, A., Suleyman, H., Karagoz, Y., Bayir, Y., and Halici, M. 2005. Antioxidant activity, reducing power and total phenolic content of some lichen species. Fitoterapia. 76, 216-219.

9. Hajimahmood, M., Sadeghi, N., Jannat, B., Oveisi, M.R., Madani, S., Kiayi, M., Akrami, M.R., Ranjbar, A.M. 2008. Antioxidant Activity, Reducing Power and Total Phenolic Content of Iranian Olive Cultivar. J. Biol. Sci. 8, 779-783. 